\title{
Form-focused instruction (FFI) and language features attended to during content-based instruction (CBI) lessons at a southeastern Mexican university
}

La instrucción centrada en la forma y los aspectos lingüísticos a los que se les presta atención durante la Instrucción Basada en Contenidos en una universidad sureña en México

\author{
Volumen 19, Número 1 \\ Enero-Abril \\ pp. 1-28
}

Este número se publica el 1 de enero de 2019

DOI: https://doi.org/10.15517/aie.v19i1.34785

\author{
Andrés Arias de la Cruz \\ Gisela Domínguez Barrera \\ Eleazar Morales Vázquez
}

Revista indizada en REDALYC, $\underline{\text { SCIELO }}$

Revista distribuida en las bases de datos:

LATINDEX, DOAJ, REDIB, IRESIE, CLASE, DIALNET, SHERPA/ROMEO, QUALIS-CAPES, MIAR

Revista registrada en los directorios:

ULRICH'S, REDIE, RINACE, OEI, MAESTROTECA, PREAL, CLACSO 


\title{
Form-focused instruction (FFI) and language features attended to during content-based instruction (CBI) lessons at a southeastern Mexican university
}

La instrucción centrada en la forma y los aspectos lingüísticos a los que se les presta atención durante la Instrucción Basada en Contenidos en una universidad sureña en México

\author{
Andrés Arias de la Cruz ${ }^{1}$ \\ Gisela Domínguez Barrera² \\ Eleazar Morales Vázquez ${ }^{3}$
}

\begin{abstract}
One of the shortcomings commonly associated to Content-based Instruction is the scarce attention teachers give to the linguistic aspects of the target language. In Mexico there are 33 public universities offering Bachelors of Arts (BAs) in English language teaching in which content courses are taught; however, very little is known about how these courses are taught and whether teachers focus on linguistics aspects of the target language or not. This article shows the results of a study carried out aiming to determine if Form-Focused Instruction (FFI) was implemented in two Content Courses at a Southeastern Mexican University as well as the type of FFI implemented by teachers. Through the use of a qualitative method, based on a descriptive case study, two teachers teaching content subjects to two groups of students $(n=55)$ in a Mexican undergraduate programme were observed. After fifteen hours of observation, lessons were analysed using the Communicative Orientation of Language Teaching (COLT) Scheme. The results showed that the participant teachers implemented only reactive FFI while no evidence of proactive FFI was found. The linguistic features attended to were mostly vocabulary, pronunciation while grammar features were barely covered. There is not a true integration of content and language in these two CB courses. CB teachers need to make use of proactive FFI to direct students' attention to less salient features of the target language.
\end{abstract}

Key words: content-based instruction, teaching methods, english teaching

Resumen: Una de las limitantes comúnmente reportada, en estudios de la Enseñanza basada en contenidos, es la poca atención que las personas docentes prestan a los aspectos lingüísticos. En México existen 33 universidades que ofrecen licenciaturas en la enseñanza del inglés, en ellas se imparten materias de contenido; no obstante, se sabe poco sobre cómo se dan estas materias y acerca de si los profesores ponen atención a aspectos lingüísticos. Este artículo presenta los resultados de un estudio llevado a cabo con el objetivo de determinar si se implementa la instrucción basada en la forma, en cursos de contenido, en una universidad sureña en México. Asimismo, se muestra el tipo de instrucción basada en la forma, que implementan las personas docentes. Mediante un abordaje cualitativo y a través de un estudio de casos, con un alcance de tipo descriptivo, se observó a dos docentes que enseñaban materias de contenido a dos grupos de estudiantes ( $n=55)$ de una licenciatura en lenguas modernas. Después de 15 horas de observación, las clases fueron analizadas utilizando el Esquema de Orientación Comunicativa de la Enseñanza de Idiomas o "COLT Scheme" (siglas por su significado en el idioma inglés). Los resultados muestran que el cuerpo docente implementó, solamente, una instrucción basada en la forma de manera reactiva, no hubo evidencia de una instrucción basada en la forma de manera proactiva. Los aspectos lingüísticos atendidos se limitaron a vocabulario y pronunciación, y muy escasamente a la gramática. Por lo tanto, no hay una verdadera integración del contenido y el idioma. Las personas docentes de materias de contenido necesitan implementar la instrucción basada en la forma de manera proactiva, esto para dirigir la atención del estudiantado hacia los aspectos lingüísticos menos comunes del idioma que se estudia.

Palabras clave: instrucción basada en contenidos, métodos de enseñanza, enseñanza del inglés

\footnotetext{
1 Profesor de Inglés en la Universidad Juárez Autónoma de Tabasco, México.

Dirección electrónica: andres arias cruz@hotmail.com

2 Profesora de Inglés en la Universidad Juárez Autónoma de Tabasco, México.

Dirección electrónica: giseladb1@hotmail.com

3 Profesor de Inglés en la Universidad Juárez Autónoma de Tabasco, México.

Dirección electrónica: eleazarmove@gmail.com
}

Artículo recibido: 27 de marzo, 2018

Enviado a corrección: 30 de julio, 2018

Aprobado: 17 de setiembre, 2018 


\section{Introduction}

Research based on Form-focused instruction (FFI) during Content-based instruction (CBI) has revealed that it renders positive results in students participating in $\mathrm{CBI}$ courses where FFI is implemented (Ahmadvand and Nejadansari, 2014; Bataineh, Al-Qeyam and Smadi, 2017; Lindseth, 2016; Ahmadvand and Nejadansari, 2014; Zyzik and Polio, 2008). Research in different contexts (Mexico: Arias and Izquierdo, 2015; USA: Rodgers, 2015; Zyzik and Polio, 2008; Canada: Lyster, 2007; Swain, 1996; Hong Kong: Hoare and Kong, 2008; Finland: Södegard, 2008) reveals that teachers pay little or no attention to language, which means that very limited or no FFI instruction is implemented during $\mathrm{CBI}$ lessons. This scarce implementation of FFI might generate negative impacts on students' language development; this also might explain some of the students' language problems commonly reported in CBI research (Ranta and Lyster, 2007; Swain, 1996). For example, it has been found that "a great deal of attention is paid to the students' understanding of content and little time is left to focus on language" (Burger and Chrétien, 2001, p. 98); or as stated by DaltonPuffer (2011), the attention to language is not firmly established.

So far, it is widely accepted that a combination of content and FFI is a necessary component in $\mathrm{CBI}$ lessons for helping students improve their inaccuracies of the target language (Lightbown, 2007; Spada, Jessop, Tomita, Susuki and Valeo, 2014). Results of the effect of FFI instruction come from different and varied contexts (Bataineh et al., 2017; Tedick and Young, 2014; Xanthou, 2011).

Regarding the Mexican context, there are 33 public universities offering BAs and even MAs programmes in Language Teaching in which content courses are taught via English language [Asociación Nacional de Universidades e Instituciones de Educación Superior (ANUIES), 2017], meaning these are CBI courses or more specifically Sheltered courses; "these types of courses consist on content courses taught on the second language to $a[\ldots]$ group of learners by a content specialist" (Brinton, Snow and Wesche, 2003, p. 15). Brinton, Snow and Wesche (2003) continue explaining that in Sheltered courses "the primary goal is to help students master content material $[. .$.$] in a pure sheltered model, [\ldots]$ it is the content instructor who has sole responsibility for content and language instruction" (p. 18). As for this definition, it clearly describes courses commonly taught in many Mexican public universities offering Bachelors of Arts and Masters of Arts in language teaching, modern languages teaching or more specifically BA and MA programmes which train students to be teachers of 
the English language. Nonetheless, as far as it is known, there is scarce evidence of studies, at least at university level, conducted focusing on the implementation of these content courses and much scarcer is the evidence of the implementation of FFI in these content courses in Mexico. Thus, this study aims at determining the existence or absence of $\mathrm{FFI}$ in content courses at university level in Mexico and in the event of finding some evidence of $\mathrm{FFI}$; this study also aims at determining the type of FFI commonly implemented by Mexican CBI teachers at university level.

\section{Theoretical Framework}

\subsection{Definition of Form-focused Instruction}

In an attempt to define Form-focused Instruction (FFI), the revision of available literature reveals that most researchers agree on the definition and understanding of the term as moments in which some attention is given to linguistics features of the target language. For example, Ellis, Basturkmen and Loewen (2002) claim that "Focus-on-form' refers to a particular type of form-focused instruction - the treatment of linguistic form in the context of performing a communicative task" (p. 419). In the same vein, Spada (1997) refers to FFI as "any pedagogical effort which is used to draw the learners' attention to language form either implicitly or explicitly..." (as cited in Lyster, 2007, p. 43). From Ellis et al.'s (2002) definition, it is evident that FFI takes place in meaning oriented contexts where the primary focus is on content rather than on linguistics features. Spada's (1997) definition evidences the core objective of FFI: content teachers' effort to provide students with activities that direct students' attention to specific aspects of the target language (as cited in Lyster, 2007). Similarly, Costa (2012) claims that FFI is "understood as occasional moments of linguistics focus (language as an object) within more general moments focused on content (meaning as an objectlanguage as a vehicle)" (p. 33).

\subsection{Types of FFI}

Regarding the types of $\mathrm{FFI}$, different types have been proposed: explicit, implicit, isolated, integrated, planned, incidental, proactive, reactive, intensive, extensive and Preemptive Focus on Form (FonF). Explicit FFI occurs when teachers provide "overt instruction and corrective feedback, including the use of meta-language and clear signals to the learners that there was a right and a wrong way to say/write something" (Spada, 2011, p. 227). And 
implicit FFI which is implemented in an indirect way by massively exposing students to a specific language feature but without making them aware of the language feature they are being exposed to (Trahey and White 1993; Trahey, 1996 as cited in Spada, 2011, p. 227). Isolated or Integrated is another type (Spada et al., 2014); Planned and Incidental is another classification of FFI proposed by Ellis, et al. (2002). Lyster (2015) refers to Ellis et al.'s (2002) classification and calls these types of FFI Proactive and Reactive. Either way: Planned or Proactive FFI refers to the type of FFI that is well planned in advanced and aims to allow the students to see and to use structures of the target language that are unlikely to be learned by just being exposed to them through input in the classroom (Lyster, 2015, p.5). On the other hand, Incidental or Reactive "occurs in response to students' language production during teacher-student interaction and includes corrective feedback as well as other attempts to draw learners' attention to the target language." (Lyster, 2015, p.5). Main differences between these two types of FFI lay in the following: proactive FFI is planned well before a lesson takes place; during the planning stage of a lesson, the teacher selects the language feature that he or she wants his or her students to focus their attention on; whereas reactive FFI addresses language challenges in the moment students make mistakes related to a given language feature (Tedick and Young, 2014), this means, while a lesson is in progress in the language classroom.

The number of language features that are addressed during FFI is another distinctive aspect or better named by Ellis (2001), intensive or extensive. In proactive FFI, the instruction is intensive given that students deal with only one language feature a good number of times (Ellis, 2001, p.16). In the case of reactive FFI, the instruction is extensive "because a range of linguistic forms (grammatical, lexical, phonological, pragmatic) are likely to arise as candidates for attention" (Ellis, 2001, p.16). During a lesson, a teacher may draw students' attention to more than one linguistic form as a teacher considers it necessary. Another important difference between Proactive and Reactive FFI is that "Proactive FFI strategies often draw on components from cognitive theory that include noticing, language awareness, and practice activities."(Tedick and Young, 2014, p. 786). "At least two phases are required for learners to notice target features in a manner robust enough to make the form available as intake: a noticing phase and an awareness phase" (Lyster, 2007, p. 66). The noticing phase is important as it serves as a catalyst for "drawing learners' attention to problematic target features that have been contrived to appear more salient and/or frequent in oral and written 
input" (Lyster, 2007, p. 66). During the awareness phase, students engage in activities in which they have to carry out some analysis of the language features; these can be implemented through tasks in which students have to work out the rules underlying a specific language feature as well as to carrying out comparisons and contrasts of patterns of the target language accompanied by some metalinguistic information (Lyster, 2007, p. 66).

Eleven types of techniques have been highlighted in the literature in order to implement proactive FFI, consciousness-raising tasks, input enhancement, task-essential language, input flood, negotiation, recast, output enhancement, interaction enhancement, dictogloss, input processing, and garden path (Bataineh, Al-qeyam, and Smadi, 2017). In Reactive FFI, interventions are made by teachers in the form of interactional feedback (Lyster, 2007) to lead students to focus on the language system. Lyster and Ranta (1997) classified teachers' feedback into six types: "explicit correction, recast, clarification request, metalinguistic feedback, elicitation, and repetition" (p.44). Lyster and Mori (2006) grouped these six types into three "feedback moves can be classified as one of three types: explicit correction, recasts, or prompts" (p. 271). Recast is defined as restating what a student has just said but without the error or errors he or she committed (Lyster, 2007, p. 93). In the case of explicit correction, the teacher provides the correct form along with an indication that what has just been said was wrong (Lyster and Mori, 2006, p. 271). Prompts include: clarification request, metalinguistic feedback, elicitation, and repetition and are defined by Lyster and Mori (2006) as follows:

a) elicitation, in which the teacher directly elicits a reformulation from the student by asking questions such as "How do we say that in French?" or by pausing to allow the student to complete the teacher's utterance, or by asking the student to reformulate his or her utterance; b) metalinguistic clues, in which the teacher provides comments or questions related to the well-formedness of the student's utterance such as "We don't say it like that in Japanese"; c) clarification requests, in which the teacher uses phrases such as "Pardon?" and "I don't understand" after learner errors to indicate to students that their utterance is ill-formed in some way and that a reformulation is required; and d) repetition, in which the teacher repeats the student's ill-formed utterance, adjusting intonation to highlight the error. (p. 271) 
In her study of English-medium science lecturers in Italy, Costa (2012) proposed a Taxonomy of Pre-emptive Focus on Form (FonF); she claims that this type of FonF has been referred to as implicit or incidental in previous research. Pre-emptive FonF is defined as "occasions when either the teacher or a student chooses to make a specific form the topic of the discourse" (Ellis, Basturkmen and Lowen, 2001, p. 407 as cited in Costa, 2012, p. 34). According to Costa (2012), "Pre-emptive FonF can involve language features related to grammar, vocabulary and phonology" (p. 34). Grammatical FonF implies that a lecturer focuses on a grammar element during a discourse on meaning (Costa, 2012, p. 37). In a lexical FonF, a lecturer provides or explains the meaning of a lexical feature (Costa, 2012, p. 37).

\subsection{Neglected attention to language as a shortcoming source of $C B I$}

Various and different $\mathrm{CBI}$ shortcomings sources have been reported, such as lack of interaction with native speakers of the target language and lack of feedback; nonetheless, the most common and frequent source of shortcoming that researchers have identified is that $\mathrm{CBI}$ teachers tend to pay more attention to meaning than to form (Airey, 2012; Burger and Chrétien, 2001; Costa, 2012; Lyster, 2007; Rodgers, 2015; Zyzik and Polio, 2008). This overwhelming attention to meaning negatively impact students' leaning as attested by the different researches conducted in varied learning contexts. For instance, in several studies conducted on immersion programs, it was found that, in $\mathrm{CBI}$ contexts, teachers tend to place more emphasis on the subject matter content while neglecting the linguistic features, and, in doing so, teaching falls short in maximizing L2 learning (Lyster, 2007; Rodgers, 2006). Lyster (2015) explains that "tasks undertaken on immersion typically aim to engage students with subject matter" (p. 12). Swain (1996) is even more emphatic about how this neglected attention to language affects students' language development: "their spoken and written use of the target language often contains morphological and syntactic inaccuracies, lacks precision in vocabulary use" (p. 531). Moreover, Ranta and Lyster (2007) report that immersion students are "non-idiomatic in their lexical choices and pragmatic expressions" ( $p$. 143). Even more, it has also been found that there are major gaps on immersion students' oral and written grammar (Lindseth, 2016; Zyzik and Polio, 2008).

As a result, oral and written grammar have been identified as of paramount importance if education on immersion and Content-based contexts is to thrive (Day and Shapson, 2001). 
Tomita and Spada (2013) supports this view arguing that "a focus on language form played an important role in the type of the L2 learner communication" (p. 606). Swain (1996) also endorses this suggestion and points out that "the need to integrate language teaching and content teaching [is] clear" (p. 48). In the same vein, Asadi and Gholami (2014) state that a focus on language is necessary for students' acquisition of the target language to occur. This need for attending to form and content is further addressed by Lyster (2007) who hypothesizes that many of the students' language problems could be overcome if content and language are systematically integrated. Lyster (2007) goes further saying that when teachers do not directly attend to language, learners may not receive sufficient and extended language development necessary to achieve high levels of proficiency. Bataineh et al., (2017) also recommend that teachers make use of FFI as its effectiveness has been demonstrated.

Altogether, empirical research has yielded firm evidence that a focus on language is necessary if students are helped to move beyond their language level, improve their target language, and correct their language inaccuracies commonly found in CBI clientele (Airey, 2012; Arias and Izquierdo, 2015; Costa, 2012; Lindseth, 2016; Loewen, 2005; Lyster, 2007; Lyster and Mori, 2006; Marzban and Mokhberi, 2012; Swain, 1996; Zyzik and Polio, 2008).

\subsection{Type of Language Features Teachers Pay Attention to During CBI}

Up to now, FFI has been investigated and implemented in many and different types of contexts, students and levels. As stated above, FFI implies directing students' attention to language features; nonetheless, here it is convenient to bring about a statement posed by Cammarata and Tedick (2012) who describe it as a "pedagogical journey whose success is intricately linked to the quest and challenge of figuring out what language to focus on in the context of content instruction" (p. 257) or as proposed by Dalton-Puffer (2011) there is a need for "identifying subject-specific language use in terms of lexicon and genres for various content areas" (p. 196).

This section presents the different language features, reported in the literature, that teachers pay attention to during CBI. After a revision of one hundred and seven lesson plans created by practicum teachers at the final stage of an MA TESOL program, Baecher, Farnsworth and Ediger (2014) concluded that teachers often focused on "vocabulary, and considerably less often on grammatical structures, functions or language learning strategies" (p. 131). Derived from their study, Zyzik and Polio (2008) reported that FFI was very common; 
although, the focus was exclusively on vocabulary. Baecher et al., continue explaining that when there was a focus on grammar, teachers primarily concentrated on verb tenses such as simple present or past or adjective; they also claim that "the only other structures featured several more than once- were transition words (either sequence words or comparison/contrast words), identifying parts of the speech (noun, verb, adjective, adverb only), and sentence structure (involving peer correction of sentences in writing)" (2014, p. 131).

Similarly, in a study conducted in Italy, Costa (2012) found that the attention to form given by Italian lectures was not very high as the total number of times in which language received some attention was very low. From the over sixteen hours of observation, there was evidence of only 76 episodes of focus on form distributed as follows: lecturers focus on lexical items in 25 episodes, basically in this type of focus on form, "a lexical element is explained or its meaning provided" (Costa, 2012, p. 38); only in four episodes lecturers focused on grammar in which the lecturer dealt with a grammar element in the case of Costa's observations, and the only grammar featured addressed by the lecturers observed was related to the use of modals (Costa, 2012). There were twelve episodes in which there was a focus on typographical input enhancement, this means, instances in which the input was made visible to students through the underlining of some key terms in the handouts (Costa, 2012). Finally, 35 occurrences of codeswitching were coded, that is, moments when attention is paid to explaining by translating lexis (Coonan, 2007 and Girsai, 2008 as cited in Costa, 2012, p. 42).

Kamiya (2012) conducted a study where two English classes in a public high school in Japan taught by a native speaker of English were observed. Results showed that the teacher; on the one hand, proactively focused exclusively on lexicon where the instructor frequently asked students about the meaning of the new vocabulary in the material they were using (Kamiya, 2012). On the other hand, the teacher, most of the time, showed a reactive focus on form as " $63 \%$ of the time when the teacher focused on form concentrated mainly on pronunciation, followed by lexicon with $23 \%$ and grammar with only 14\%" (Kamiya, 2012, p. 393).

Nakatsukasa and Loewen (2015) investigated a teacher L1 use during Focus-on-form Episodes (FFEs) in a Spanish as a foreign language classroom at a US university. Derived from the 12 hours of videotaped lessons, the researchers identified the linguistic areas that 
the teacher, mainly, focused on concluding that when the teacher used the L1 and focused on form, they mainly targeted grammar (48\%), followed by vocabulary (36\%), and semantics $(11.5 \%)$.

Likewise, in a study conducted at a university in Catalonia in Spain, Arnó-Marciá and Mancho-Barés (2015) discovered that "teachers made use of L1 or the careful planning of discourse with elaborated definitions" to focus on form (Arnó-Marciá and Mancho-Barés, 2015, p. 67); even more, when there was a breakdown in communication, the teacher demanded for clarification from students, which generated a repair exchange on the mispronounced lexical feature.

Aiming to describe the implementation of $\mathrm{CBI}$ at the faculty of Arts and Sciences in a state university in Turkey, Bozdoğan and Karlıdağ (2013) collected data through observations and interview of participants of content classes and laboratory work courses. Data revealed that teachers explained terminology in English through morphological analysis, and "teachers explained the root and affixes of the content vocabulary[...]Finally, for instance, a teacher "switched to Turkish to give the Turkish equivalent" (Bozdoğan and Karlıdağ, 2013, p. 1156).

In comparison, from the Chinese context, Kong and Hoare (2011) reported that when addressing language, teachers tended to direct attention to language and vocabulary for classification. Derived also from a Chinese context, Kong (2009) gave an account of four content-based second language lessons at the middle school level. Results revealed that when drawing students' attention to language, teachers mainly concentrated on grammar: the use of cause-effect, the if-conditional; on morphology: the spelling of the word lens, and the pronunciation of a few words.

Regarding to the Mexican Context, Arias and Izquierdo (2015) reported that from the two $\mathrm{CBI}$ teachers observed at a university level, whenever they drew students' attention to language, they mainly addressed vocabulary and pronunciation followed by morphology and syntax.

Based on the backdrop presented so far, the research questions guiding this study are the following:

a) Do two $\mathrm{CBI}$ teachers implement form-focused instruction at a Southeastern university in Mexico?

b) What type of FFI do $\mathrm{CBI}$ teachers under study commonly implement: proactive or reactive?

c) What language features do teachers under study pay attention to during FFI? 


\section{Method}

A qualitative paradigm was chosen for this study (Kumar, 2011) as the purpose is to describe a situation observed by the researcher and to depict the living conditions of a community. This study falls into this paradigm given that it shares some of the characteristics of this paradigm: it aims at observing, analysing, and describing the teachers CBI lessons, through the use of the observation as the main investigative instrument (Mackey and Gass, 2005). More specifically, this study takes the form of a case study allowing "investigators to focus on a "case" and retain a holistic and real-world perspective- such as in studying individual life cycles, small groups behaviour, organizational and managerial process [...] school performance [...]" (Yin, 2014, p. 4). The present descriptive case study involves the case of two university teachers at one Mexican university and attempts to describe systematically how $\mathrm{CBI}$ lessons unfold regarding $\mathrm{FFI}$, and at the same time, it provides information about the type of language features that teachers pay attention to during FFI (Kumar, 2011, p. 30).

The two courses and the two teachers of this case study were selected based on two criteria: availability of content subjects at the time of the study and availability and disposition of the teachers to participate. Finally, it is important to stand out that the results obtained from a case study is difficult to generalise. In fact, generalization in science is rarely based on single experiments (Yin, 2014, p. 20). Consequently, the results of this case study are difficult to generalise to other universities in Mexico due to the inherent nature of the type of study and the limited number of cases addressed.

\subsection{The Context}

The research site for the present study was a B.A. program in Modern Languages at a Southeastern Mexican university. This undergraduate program aims at training students to become professionals in the field of Modern languages. Inside this undergraduate program, the courses taught can be classified depending on the language of instruction: courses taught in the L1 or L2. Moreover, the L2 courses can be classified into language arts and contentbased courses. For the purpose of this study, only the latter type of courses was of interest.

Out of the 25 ESL courses taught as part of this BA program, twelve of them are delivered via CBI. The two $\mathrm{CBI}$ courses in which this study was based on were Culture of English Speaking Countries and Teaching Aids. 
The main objective of the Culture of English Speaking Countries course is to analyze the main historical, artistic and social events of English speaking countries in order to understand their culture. It has a total of 40 hours and is taught in the third cycle of the BA program. The main objective of the Teaching Aids course is to provide students with the theoretical foundations supporting teaching aids so that students are able to create the appropriate teaching aids for a specific given teaching situation. It also has a total of 40 hours and is taught in the eighth cycle (Universidad Juárez Autónoma de Tabasco, 2010).

\subsection{The Teachers}

The two participating teachers, a 46 female and a 44 male, who took part in this study, taught content courses at the B. A. in Modern languages. The female teacher was teaching Culture of English Speaking Countries and the male teacher was teaching Teaching Aids. In reference to their teaching training, both graduated from the same B.A. in Modern Languages in which they were teaching and both have taught both English language arts and contentbased courses for more than 15 years in the B.A. programme. Researchers got the teachers' consent by talking to them; although, they did not sign up any written consent.

\subsection{The Students}

All the students participating in this study were Mexican and had Spanish as their L1. All of them came from the Southeast part of Mexico. At the beginning of this study, the students' ages ranged from 19 to 25 . The 55 students participating in this research project were enrolled in two groups: 25 enrolled in the Culture of English Speaking Countries group and 30 in the Teaching Aids one (Universidad Juárez Autónoma de Tabasco, 2010). These students were selected as they were enrolled in the only two content courses that were available at the time of carrying out this research project and as they were enrolled in the groups of the teachers that were willing to participate in the study. Just as for the teachers, researchers got the students' consent by talking to them and explaining the research objectives; although, they did not sign up any written consent.

\subsection{Data Collection}

Data was gathered through video recordings during a month and a half-long observational period based on video-recordings of classroom activities. During the video 
recording period, visits to classrooms were limited to once a week for the Culture of English Speaking Countries course, since every lesson consisted of a three hours session once a week. For the Teaching Aids course, lessons took place twice a week; lessons lasted for one hour long on Mondays and on Thursdays lasted for two hours. The final database included 9 hours of video-recording for the teacher of Culture of English Speaking Countries Content course, distributed across three sessions; and six hours of video recordings for the Teaching Aids content course, distributed among one-hour and two two-hour lessons.

\subsection{Data Coding Procedure}

Video-recording lessons were transcribed following the Transcription Conventions for the Second Language Classroom (Mackey and Gass. 2005. p. 345). The video transcriptions were coded and analysed using Spada and Fröhlich's (1995) Communicative Orientation to Language Teaching (COLT) scheme. COLT describes features of teaching practices (Spada and Fröhlich's, 1995, p. 1); additionally, COLT categories can be used to describe both meaning-oriented classrooms and form-oriented ones (Spada and Fröhlich, 1995).

Part $A$ of COLT has seven main features: Time, Activities and Episodes, Participant Organisation, Content, Content Control, Student Modality and Material. Regarding the purpose of each feature: the time feature is used to enter the starting time of an activity or episode. The Activities and Episodes are segments of a lesson; the Participant Organisation feature refers to the way in which students are organised in the classroom; Content refers to the subject matter or the theme of activities; Content Control deals with observing who is in charge of choosing the topic of a lesson; the Student Modality feature is useful to identify the skills students use to perform a language activity, and finally the Material identifies the type and source of material used in a lesson.

Given the aims, only the Content feature was directly related to this research. The content feature has 3 categories: Management, Language and Other Topics. Only the Language category served the purpose of this study.

The Language category of COLT has the following categories: form, function, discourse and sociolinguistics. As stated before, the Language category from Part A of COLT came to be the cornerstone of this study as it allows to capture the instances in which a teacher focuses on linguistic aspects of the target language (Spada and Fröhlich, 1995). 


\subsection{Data Analysis}

The analysis of the data involved two stages: 1) the identification of activities and episodes, and 2) the codification of the episodes into the COLT scheme, more specifically into the language category.

This identification of Activities and Episodes was made following the COLT Coding Convention Manual (Spada and Fröhlich, 1995). To determine where an activity begins and ends, this COLT indication was observed: an activity is marked when there is a change in the theme or content of the lesson. So, during the analysis of the scripts, whenever a change in the overall theme of the lessons under analysis was detected, it was marked as a new activity. Thus, the length of each activity counted from the minutes and seconds a teacher started a topic to the minutes and seconds the teacher started a new topic or theme. Regarding the episodes, the COLT Coding Convention Manual states that an episode can be distinguished when there are shifts within the categories; a category is understood as the different parts a feature is divided into, and in the case of the classroom organization feature, the categories are class, group and individual (Spada and Fröhlich, 1995, p. 30). Moreover, episodes refer to any teaching/learning behaviour that takes approximately a minute or longer (Spada and Fröhlich, 1995, p. 33). Within the activities, the length of each episode was counted from the minute and seconds in which there was a shift to one category to the minutes and seconds in which there was a shift to another category. In the end, once each lesson script was broken down into activities and episodes, researchers just counted the number of activities and episodes to have the total number for each teacher. Table 1 and 2 below show the total number of activities and episodes found in the lessons under analysis

Table 1

Synoptic table showing the number of episodes and activities and the length of each lesson of the Culture of English Speaking Countries course at a Southeastern Mexican university

\begin{tabular}{llll}
\hline Lesson & Number of Activities & Number of Episodes & Length (time hour) \\
\hline Lesson 1 & 8 & 84 & $3 \mathrm{~h}$ \\
Lesson 2 & 7 & 98 & $3 \mathrm{~h}$ \\
Lesson 3 & 5 & 95 & $3 \mathrm{~h}$ \\
\hline Total & $\mathbf{2 0}$ & $\mathbf{2 7 7}$ & $\mathbf{9}$ \\
\hline
\end{tabular}

Source: adapted from Spada and Fröhlich (1995) 
Table 2

Synoptic table showing the number of episodes and activities and the length of each lesson of the Teaching Aids course at a Southeastern Mexican university

\begin{tabular}{llll}
\hline Lesson & Number of Activities & Number of Episodes & Length (time hour) \\
\hline Lesson 1 & 5 & 33 & $1 \mathrm{~h}$ \\
Lesson 2 & 2 & 21 & $2 \mathrm{~h}$ \\
Lesson 3 & 1 & 24 & $1 \mathrm{~h}$ \\
Lesson 4 & 2 & 46 & $2 \mathrm{~h}$ \\
\hline Total & $\mathbf{1 0}$ & $\mathbf{1 2 4}$ & $\mathbf{6}$ \\
\hline
\end{tabular}

Source: adapted from Spada and Fröhlich (1995)

As tables 1 and 2 above display, the observations of the two CBI courses covered 15 hours of observations with a total of 30 activities and 401 episodes.

\section{Results}

In the light of the description of the literature review and in an attempt to illustrate in detail the specific language features the CB teachers focused on the lessons observed, and the occurrences of FFI in the lessons under observation in this study have been categorised as:

a. Pronunciation, in which, during discourse focused on meaning, the pronunciation of a word or phrase is provided (Saito and Lyster, 2011).

b. "Lexical, in which, during a discourse focused on meaning, a lexical element is explained or its meaning provided" (Costa, 2012, p. 37).

c. "Grammatical, in which the lecturer deals with a grammar element during a discourse on meaning" (Costa, 2012, p. 37).

The codification of the episodes into the COLT scheme, more specifically into the language category, yielded the following results regarding the lexical, phonological and grammatical aspects and are presented in decreasing order of number of occurrences in the tables below.

For lessons 1, 2 and 3, the teacher of the Culture of English Speaking Countries focused on language as there were 119 times in which the Form category of the COLT Scheme was checked as the table 3 reveals. 
Table 3

Language features the teacher of the Culture of English Speaking Countries course paid attention to at a Southeastern Mexican university.

\begin{tabular}{cccc}
\hline Language Feature & Lexical & Phonological & Grammatical \\
\hline Lesson 1 & 12 & 15 & 2 \\
Lesson 2 & 29 & 35 & 7 \\
Lesson 3 & 16 & 3 & 0 \\
\hline Total & $\mathbf{5 7}$ & $\mathbf{5 3}$ & $\mathbf{9}$
\end{tabular}

Source: adapted from Spada and Fröhlich (1995)

For lessons 1, 2, 3 and 4, the teacher of the Teaching Aids course also focused on the language as there were 26 times in which the Form category of the COLT Scheme was checked as table 4 reveals.

Table 4

Language Features the teacher of the Teaching Aids course paid attention to at a Southeastern Mexican university.

\begin{tabular}{cccc}
\hline Language Feature & Lexical & Grammatical & Phonological \\
\hline Lesson 1 & 9 & 6 & 3 \\
Lesson 2 & 0 & 0 & 0 \\
Lesson 3 & 0 & 0 & 0 \\
Lesson 4 & 2 & 3 & 3 \\
\hline Total & $\mathbf{1 1}$ & $\mathbf{9}$ & $\mathbf{6}$ \\
\hline
\end{tabular}

Source: adapted from Spada and Fröhlich (1995)

The data from the tables of the teachers of both courses show that they focused mainly on the lexical feature as this language feature had the highest number of occurrences: 68, followed by phonological feature with 59 number of occurrences, and being the grammatical features the least attended to with only 18 number of occurrences.

The following section gives examples from the corpus of the language features the teachers of the Culture of English Speaking Countries and Teaching Aids courses targeted during FFI.

\subsection{Lexical FFI}

According to Costa (2012), a lexical FFI is understood as an explanation or the provision of the meaning of a lexical element. Some examples of them were found in the lessons observed and are included down below. 
Extract (1) comes from the corpus of the Culture of the English Speaking Countries course. Here, a couple of students were making a presentation in PowerPoint; this episode of the lesson included the explanation of the economy of the Scottish Highlands in the eighteenth century. During this episode, one of the students used the word landlord, as this is not a very salient word in the common school discourse; the teacher of the Culture of English Speaking Countries focused on this lexical item by defining the word.

Student: "Europe [...]in this picture eh... say...say that other many people left their small houses in the eighteenth century to find work in the large towns but other persons were landlords who want to use their lands [...] ehh [...] until a new law was introduced in 1986."

Teacher: "Do you know what a landlord is, a landlord [...] no? well, a landlord is a person who owns large extensions of land [...]. A person who owns big parts of a town [...]. And he has people living in that part of the land."

Extract (2) comes from the corpus of the Teaching Aids subject; the topic was the Overhead Projector (OHP), and this episode specifically focused on the disadvantages of the OHP. Students were reading some handouts with information about the different disadvantages of this teaching resource teachers had once at hand; a student asked to the teacher for the meaning of the phrase keep on. The teacher provided a synonym and made gestures to provide the meaning of the phrase in question:

Student: "Teacher: we don't understand, keep on is [...] is like a [...]?"

Teacher: "To keep on [the teacher makes gestures with his hand to indicate moving forward], to keep on is the same as to continue."

Extract (3) comes from the corpus of the Culture of the English Speaking Countries course; a student was presenting some information about England. This episode focused on describing a city of England. In this episode, the word metropolitan appeared and the teacher felt the necessity of making the meaning of this word clear for students. Subsequently, to show that the teacher wanted students to clearly understand the word, he or she elicited some ideas from students and provided some examples that were familiar to students as attested by the extract below: 
Student: "The formation of this city was in [nonaudible] and most of it was incorporated into a nonmetropolitan county. A nonmetropolitan county, it means not metropolitan but almost."

Teacher: "What is the meaning of metropolitan?"

Student: "Almost a metropolitan"

Teacher: "What is metropolitan?"

Student: "Metropolitan is a city [nonaudible]"

Teacher: "Like a large city [...] like an important city, if we talk about Tabasco, what is the metropolitan city?"

Students: "Villahermosa?" [rising the intonation]

Teacher: "Why? Because [it] is where the government, the commercial activities and everything is located, that is the metropolitan city. If we talk about Mexico, what are the metropolitan cities in Mexico? If we talk about our country: Mexico City, Monterrey, Guadalajara, Puebla."

In extract (4), the teacher of the Teaching Aids course focused on a lexical item by providing a synonym of the word asked by some students. In this extract, students were reading some handouts and there was a term that a couple of students did not understand and they asked the teacher. The teacher provided a synonym of the phrase students were asking for and went beyond by also providing the Spanish equivalent as shown in the extract below:

Student: "What is the meaning of wash up?" [pointed at the text]

Teacher: "It means [...] wash up means to clean something (making gestures of washing up[...] lavar", [nonaudible as the teacher whispered].

\subsection{Phonological FFI}

This section presents examples of phonological FFI, in which the teacher drew students' attention to a phonological element while focusing mainly on meaning. In all of the instances found in the corpus of both $\mathrm{CBI}$ courses, the teacher focused on the language only as a reaction to students' mispronunciation of a word or phrase.

Extract (5) comes from the corpus of the Culture of English Speaking Countries course; here, some students were explaining some current facts about England and Scotland; during 
the explanation, one of the students mentioned the word proclaimed, providing an erroneous pronunciation of this word, something like: /prokleimed/. The teacher reacted immediately and provided the correct pronunciation of the word proclaimed: /prəkleimd/. See the extract below: Student: "Also, I am going to talk about the [...] the history the England [...] the England and Scotland; when Scotland fought her last battle against the English in seventy-seven a special treaty united the governments of Scotland England. And there is a famous person in this history and his name is the prince Charles [...] Charles [...] he [...] mmm [...] he spent 20 years in Roma preparing to [nonaudible] the crown of Great Britain for his father and himself, and he [...] then he returned to Scotland and [nonaudible] $\mathrm{mmm}$ [nonaudible] he was proclaimed /prokleimed/ king of [nonaudible]."

Teacher: "/prəkleimdl" [teacher provided the correct pronunciation]

In extract (6) the teacher of the Teaching Aids course and his or her class were discussing some of the benefits overhead projectors provide to teachers. One of the students mentioned that one benefit was that with the OHP, teachers can show diagrams. The student mispronounced the word by saying something like this: /drəgræms/" The teacher recasted the student's wrong pronunciation and provided the correct one: /darəgræmz/.

Teacher: "All right! the first point, advantages!"

Group: "The first advantage."

Teacher: "Yea, the first advantage, I mean that [nonaudible]"

Student: "Ok. In this case the advantage in this part is [...] eh, in the over projector [...] you can show diagrams:/diəgræms/."

Teacher: "Diagrams/daIəgræmz/" [the teacher corrects the pronunciation]

In extract (7) there is one more example coming from the Culture of English Speaking Countries course; a student was explaining some facts about London; during his or her explanation, the student used the word southeast. Nonetheless, he or she pronounced the word incorrectly, saying something like: /spvei:st/. Immediately, the teacher reacted and provided the correct pronunciation of the word: /sav $\theta i$ :st/.

Teacher: "Ok [...] ready [...]. Ok."

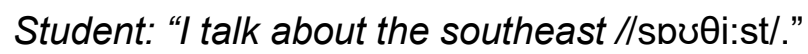

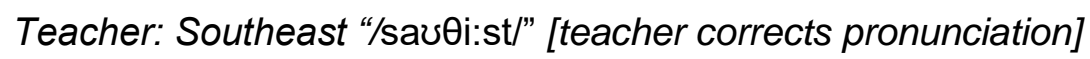




\subsection{Grammatical FFI}

This final section provides examples of grammatical FFI, in which the teacher deals with a grammar element while focusing mainly on meaning. As attested by tables 3 and 4, during the analysis of the transcripts of the lessons of both teachers, very few examples of this type of $\mathrm{FFI}$ instruction were found.

In extract (8) a student was talking about some pictures showing some interesting natural attractions of Northern Ireland. It happened that this student used the superlative form of the adjective large; nonetheless, the students formed the superlative of this adjective incorrectly by saying the most large. The teacher reacted to this student's grammatical inaccuracy and provided the correct form of the superlative: the largest. The extract has been inserted below to exemplify this:

Student: "Ok, here you have 4 pictures and for example this [...] this is a mountain, can you see? The name is the mountain of McMorrow this mountain is located obviously in Northern Ireland, in the city of county down. The best way to reach this mountain is [nonaudible] so this mountain is very important in this city because people go to visit it. So, we have the "Wolf" and it [nonaudible] for example one kilometre or something like that, and this is, this is a [...] this is a lake, I remember this is the most large."

\section{Teacher: "The largest."}

Student: The largest city and this is the [...] $\mathrm{mmm}[. .$.$] this is in the north of Ireland and$ this, this area is, very, very big, and these places are the most visited in this country, that is Northern Ireland.

In extract (9) a student was explaining how to use an activity as a teaching resource. Throughout her explanation, the student came to explain where she took the activity from and said that she took it of a book. The teacher took over and provided the correct preposition: "from a book, I took it from a book."

Student: "Emm [...] I'm going to use this activity in my Italian class, this is [...] $\mathrm{mm}[\ldots]$ an activity taken for [...] $\mathrm{mmm}[. .$.$] for a book."$

Teacher: "from a book"

Student: "from a book? Ok. from a book [...] mmm [...] in the first part, you have to [...] you have to complete [nonaudible] 
In extract (10) a couple of students were explaining to the class some facts about Canterbury Castle. Students explained that an interesting fact about this castle was that there was a murder in this place. Nonetheless, although the victim was well-known, the case never went public as the dominant church had some interest not to make it public. During the explanation, one of the students used the phrase: the church had too many power. As a reaction to this grammatical error, the teacher provided the correct sentence: the church had a lot of power. See extract below.

Student: "in that century, the... the church had too many power."

Teacher: "a lot of power" [teacher provides the correct form of the sentence]

Student: "a lot of power"

\section{Discussion}

The present study aimed at finding out if two CB teachers at a Southeastern Mexican university implement or do not implement FFI; in addition, it sought to determine the type of FFI implemented by these teachers, as well as the type of language features the participant teachers pay attention to during FFI. The research questions posed for this study were: a) Do two CBI teachers implement form-focused instruction at a Southeastern university in Mexico? b) What type of FFI do CBI teachers under study commonly implement: proactive or reactive? c) What language features do teachers under study pay attention to during FFI?

Regarding question one, results show that the two teachers teaching CB courses at the university selected for the study do implement FFI instruction; nonetheless, the implementation of FFI in this context is too distant from a true integration of content and language as attested by over 400 episodes of classroom observation; in this study, out of which teachers implemented FFI only in 145 episodes. This number constitutes just the $31 \%$ of the total number of episodes in which teachers took advantages of the opportunities that these types of lessons offered to integrate language and content. This means that teachers are not maximizing the opportunities that these types of lessons offer for students to be exposed and consequently to acquire less salient language structures and to move beyond their current level. Even more, these lessons are fertile periods for teachers to implement counter-balanced activities that make students aware of language structures they might have learned or acquired incorrectly. Nonetheless, most of the time, around 69\% of the episodes; teachers concentrated on the content of the lessons. These results mirror what has been 
found in other research where CB teachers see the attention to language as of secondary importance (Airey, 2012; Arias and Izquierdo, 2015; Arnó-Marcía and Mancho-Barés, 2015, Costa, 2012; Dalton-Puffer; 2011; Rodgers, 2015). What is more, many of the students' inaccuracies in the target language went unaddressed by the two instructors (e.g. Lyster, 2007; Rodgers, 2006; Rodgers, 2015; Swain, 1996; Zyzik and Polio, 2008). To exemplify this, below there is an extract taken from the teacher of the Teaching Aids course, lesson 3 . In this episode, a student was explaining the way to implement a worksheet he or she created (inaccuracies are bolded)

Student: With a... little reading, it was took from a book, was typed. So you are supposed to read the information and then [a word in Spanish] we are gonna to ask you about the vocabulary in the reading. Obviously at this level, you know...the vocabulary of types of movies, but you don't know what are the elements on a movie, for example, the budget, the plot, that kind of... that kind of stuff. And finally, for practice, eh[pause]you are supposed to [pause] have a little discussion about the, a movie the one you like the best. Eh, this is, an oral practice because the students work in pairs or in teams, and... and we are, we have think about the movie. So, the students has to move around the class and tell about the story, the plot, the main character, and the others eh... has to guess what was the movie. So it was a... a free practice.

Teacher: Thank you. Who is next? Ok... Jovanny? No? ok...

As it can be observed, during the explanation, the student made several errors related to language. However, at the end of this explanation, the teacher just thanked the student, showing he was only concerned about the content explained; this result equals that of ArnóMarcía and Mancho-Barés' (2015) who concluded that lecturers focus much more on content than on language. Additionally, Bozdoğan and Karlıdağ (2013) agree that it seems that in practice, the priority is given to the comprehension of the content rather than the acquisition or practice of the language. Thus, teachers are failing on achieving the content and language balance that has been proved to be necessary for students to improve their oral and written language production, avoid morphological and syntactic inaccuracies in the target language as well as to develop precision in their vocabulary and grammar (Asadi and Gholami, 2014; Lindseth, 2016; Loewen, 2005; Ranta and Lyster, 2007; Swain, 1996). 
In reference to the second question, and derived from the observations carried out of the two CB courses; the researchers, of this study, did not find evidence of any pre-planned or proactive FFI implemented by the teachers to draw students' attention to any language features; to the type described by Lyster (2015): "pre-planned instruction designed to enable students to notice and to use target language features that are otherwise difficult to learn through exposure to classroom input." (p. 5). None of the teachers made use of any of the eleven proactive FFI strategies reported in the literature: consciousness-raising tasks, input enhancement, task-essential language, input flood, negotiation, recast, output enhancement, interaction enhancement, dictogloss, input processing, and garden path (Bataineh et al., 2017). Whenever teachers implemented FFI; it was exclusively as an immediate reaction to students' inaccurate use of the target language; it means, reactive FFI (Asadi and Gholami, 2014; Tedick and Young, 2014). It is worth mentioning that both teachers implemented FFI on pronunciation through recast as the following extract shows:

Student: "Ok, well, in this case the advantage in this part is eh, in the overhead projector" [nonaudible]

Teacher: "Overhead projector" [the teacher corrects the pronunciation of the word bolded]

Here, the student incorrectly pronounced the word projector /pro'gektər/; immediately, the teacher provided the correct pronunciation /prə'dzektər/ of the word the students had just mispronounced. These results are congruent with results reported in the literature: in the Italian context (Costa, 2012); in the Iranian context (Asadi and Gholami, 2014; Marzban and Mokhberi, 2012); in the Mexican context (Arias and Izquierdo, 2015); and in the New Zealand context (Loewen, 2005) among others. Thus, teachers, in this study, are not implementing proactive $\mathrm{FFI}$, and therefore, they are preventing students from learning the less salient language features and consequently limiting students' leaning opportunities for improving the target language. Instructors at different levels need to recognise that the implementation of FFI, even at a very small scale, can be effective for students to restructured their ill-formed language (Lindseth, 2016, p. 19). This finding is a major contribution of this study as it provides much needed empirical data on the type of FFI implemented in the context of this study. By knowing how FFI takes place, and also that there is an urgent need of implementing 
proactive $\mathrm{FFI}$; teachers are in a position of designing strategies and taking actions to maximise students' learning opportunities.

The third question deals with the type of language features that CB teachers pay attention to during FFI; here both teachers focused mostly on lexical followed by phonological and grammatical features of the language. This result is congruent with findings obtained in other contexts. For example, after analysing the lesson plans of practicum teachers at the final stage of a MA TESOL program, Baecher et al. (2014) found that vocabulary was the most common focus. Bozdoğan and Karlıdağ (2013) endorse this view as they observed that content vocabulary was explained in English by the teachers.

Costa (2012) also found that "the lecturers used mainly lexical pre-emptive FonF" ( $p$. 37). Moreover, considering the phonological aspect, as shown by the results obtained in this study, when CB teachers focused on any phonological features, it was through the immediate provision of the correct pronunciation. This result is similar to the results reported by Bozdoğan and Karlıdağ (2013) that when students made pronunciation mistakes, there was an immediate correction from the teacher. Kamiya (2012) found similar results and claimed that "reactive FonF was provided for many kinds of errors: among them, pronunciation was the major focus" (p. 391). Regarding the very few instances of FFI on grammatical features, this result is comparable to Costa's (2012) because in the corpus of her study, she did not find many instances of FonF. The results in this study replicate those of Kamiya's (2012) as the third most frequently targeted language feature during FonF was grammar.

To sum up, teachers in this study paid little attention to language, implemented FFI through a reactive fashion but they did not make use of proactive $\mathrm{FFI}$ at all. Consequently, CB teachers in this context need to work hard towards a true integration of content and language and a balance between proactive and reactive FFI. Researchers have explained that this lack of integration between content and language and balance between proactive and reactive FFI are due to different varied reasons: "lecturers did not feel competent to deal with them" (Costa, 2012, p. 40). For Cot (2013), for example, this might be due to a lack of training in language teaching, which would, in turn, involve a lack of language awareness (as cited in Arnó-Marcía and Mancho-Barés, 2015, p. 71) or because it is time consuming (Zizik and Polio, 2008). Marzban and Mokhberi (2012) speculate that teachers do not wish to attend to linguistic features unless they "feel obliged to" (p. 5344). 
Finally, it is important to highlight that there were some limitations pertaining to this study. First, teachers who participated in this study were not randomly selected; instead, they were the only teachers who were teaching CB courses at the time of this study, volunteered themselves and were willing to participate. Second, only two teachers is a very limited number and is not a representative one of the whole teaching staff working at the university where this research took place. From such a small sample; it is difficult to draw any firm conclusion regarding the aim of this study. What is more, results of this study derived exclusively from video-recording observations. However, in order to have a more complete overview of what is happening in $C B$ courses in this institution; it is necessary to have the viewpoint of all the participants in these courses. Therefore, administration of research instruments; say questionnaires or interviews or both that could help us to capture the attitudes and perceptions of teachers and students would yield a more accurate picture and a deeper understanding of what is really happening in the classroom in terms of $\mathrm{FFI}$, and the language features attended to.

\section{Conclusion}

The results showed that the teacher of the Culture of English Speaking Countries course paid attention to lexical features 57 times, phonological features 53 times and grammatical features 9 times. Regarding the teacher of the Teaching Aids course, he or she paid attention to lexical features 11 times, grammatical 9 times and phonological 6 times.

It is truly interesting to find that both $C B$ teachers observed in some way or another did implement FFI in their lessons despite teaching CB subjects. Nonetheless, in all instances of FFI observed, teachers only implemented reactive FFI. Consequently, they are not taking advantage of the potential that proactive FFI has for helping students to improve the linguistic problems they might have, as well as to enable students to continue to learn language and content simultaneously (Schleppegrell, 2016). Moreover, the documented language features that both teachers paid attention to during FFI limited to only three: lexical, phonological, and grammatical while no evidence of attention to other aspects of the language such as morphology, syntax, semantic or sociolinguistic aspects were documented.

Finally, it is important to say that if CB courses are to reach their fullest potential, help students improve their inaccuracies in the target language and to thrive as well; $C B$ teachers 
need to make use of both proactive and reactive FFI and focus on more linguistic aspects than the ones documented in this study.

We would like to suggest some actions that as researchers should have planned or considered, to avoid some constraints we faced throughout the development of this study:

- Include more than one data collection instrument.

- Increase the number of teachers and courses to be observed.

- Include more hours of observation.

- It is a good idea that at least two researchers code the activities and episodes into the COLT Scheme independently. Then, get together and compare their coding; this with the intention of making the coding procedure as valid and reliable as possible.

- When video recording, try as much as possible to include microphones; otherwise, the transcription becomes a headache.

- Get as familiar as possible with part A of the COLT Scheme

- Make sure the video camera has enough storage capacity. It is a pity to interrupt the video recording just in the middle of it.

\section{References}

Ahmadvand, Mohammad and Nejadansari, Dariush. (2014). Attention to meaning and form vs. attention to meaning alone: the effect of focus on form on vocabulary retention in an EFL context. Procedia - Social and Behavioral Sciences, 98, 116-121.

Airey, John. (2012). "I don't teach language" the linguistic attitudes of physics lectures in Sweden. AlLA Review, 25, 64-79.

Arias, Andrés and Izquierdo, Jesús. (2015). Language attention in content-based instruction: the case of language instructors teaching content in a foreign language in Mexican higher education. Journal of Immersion and Content-Based Language Education, 3(2), 194-217.

Arnó-Macià, Elisabet and Mancho-Barés, Guzman. (2015). The role of content and language in content and language integrated learning (CLIL) at university: challenges and implications for ESP. English for Specific Purposes, 37, 63-73.

Asadi, Bita and Gholami, Javad. (2014). Incidental focus on form in an EFL talk-show class. Procedia - Social and Behavioral Sciences, 98, 267-275.

Asociación Nacional de Universidades e Instituciones de Educación Superior (ANUIES). (2017). Catálogo de carreras de licenciatura y posgrado. Retrieved from http://www.anuies.mx/iinformacion-y-servicios/informacion-estadistica-de-educacionsuperior/anuario-estadistico-de-educacion-superior 
Baecher, Laura, Farnsworth, Tim and Ediger, Anne. (2014). The challenges of planning language objectives in content-based ESL instruction. Language Teaching Research, 18(1), 118-136.

Bataineh, Ruba Fahmi, Al-qeyam, Fatima Rasheed, and Smadi, Oqlah Mahmoud. (2017). Does form-focused instruction really make a difference? Potential effectiveness in Jordanian EFL learners ' linguistic and pragmatic knowledge acquisition. Asian-Pacific Journal of Second and Foreign Language Education, 2, 1-11.

Bozdoğan, Derya and Karlıdağ, Buket. (2013). Neglected productive skills in content-based classes. Procedia - Social and Behavioral Sciences, 70,1152-1162.

Brinton, Donna M., Snow, Marguerite Ann and Wesche, Marjorie. (2003). Content-based Second Language Instruction. United States of America: The university of Michigan press.

Burger, Sandra and Chrétien, Marie. (2001). The development of oral production in contentbased second language courses at the University of Ottawa. The Canadian Modern Language Review, 58(1), 84-102.

Cammarata, Laurent and Tedick, Diane J. (2012). Balancing content and language in instruction: the experience of immersion teachers. Modern Language Journal, 96(2), 251-269.

Costa, Francesca. (2012). Focus on form in ICLHE lectures in Italy. AILA Review, 25, 30-47.

Dalton-Puffer, Christiane. (2011). Content-and-language integrated learning: from practice to principles? Annual Review of Applied Linguistics, 31, 182-204.

Day, Elaine M. and Shapson, Stan M. (2001). Integrating formal and functional approaches to language teaching in French immersion: an experimental study. Language Learning, 41(1), 47-80.

Ellis, Rod. (2001). Introduction: investigating form-focused Instruction. Language Learning, 51(1), 1-46.

Ellis, Rod, Basturkmen, Helen, and Loewen, Shawn. (2002). Doing focus-on-form. System, 30(4), 419-432.

Hoare, Philip, and Kong, Stella. (2008). Late immersion in Hong Kong: still stressed or making progress? In Tara Fortune and Diane Tedick (Eds.), Pathways to bilingualism and multilingualism: evolving perspectives on immersion education (pp. 242-263). Clevedon, UK: Multilingual Matters.

Kamiya, Nobuhiro. (2012). Proactive and reactive focus on form and gestures in EFL classrooms in Japan. System, 40(3), 386-397. 
Kong, Stella and Hoare, Philip. (2011). Cognitive content engagement in content-based language teaching. Language Teaching Research, 15(3), 307-324.

Kong, Stella. (2009). Content-based instruction: what can we learn from content-trained teachers' and language-trained teachers' pedagogies? The Canadian Modern Language Review, 66(2), 233-267.

Kumar, Ranjit. (2011). Research methodology step by step guide for beginners. Sage.

Lightbown, Patsy M. (2007). Fair trade: two-way bilingual education. Estudios de Lingüística Inglesa Aplicada, (7), 9-34.

Lindseth, Martina. (2016). The effects of form-focused instruction on the acquisition of subject-verb inversion in German. Foreign Language Annals, 49(1), 10-22.

Loewen, Shawn. (2005). Incidental focus on form and second language learning. Cambridge University Press, 27(3), 361-386.

Lyster, Roy and Mori, Hirohide. (2006). Interactional feedback and instructional counterbalance. Studies in Second Language Acquisition, 28(2), 269-300.

Lyster, Roy and Ranta, Leila. (1997). Corrective feedback and learner uptake, negotiation of form in communicative language classroom. Cambridge University Press, 19(1), 37-66.

Lyster, Roy. (2007). Learning and teaching languages through content: a Counterbalanced approach. Amsterdam/Philadelphia: John Benjamins.

Lyster, Roy. (2015). Using form-focused tasks to integrate language across the immersion curriculum. System, 54, 4-13.

Mackey, Alison and Gass, Susan M. (2005). Second language research: methodology and design. Lawrence Erlbaum Associated Publishers.

Marzban, Amir and Mokhberi, Mehraein. (2012). The effect of focus on form instruction on intermediate EFL learners ' grammar learning in task-based language teaching. Procedia - Social and Behavioral Sciences, 46, 5340-5344.

Nakatsukasa, Kimi and Loewen, Shawn. (2015). A teacher's first language use in formfocused episodes in Spanish as a foreign language classroom. Language Teaching Research, 19(2), 133-149.

Ranta, Leila and Lyster, Roy. (2007). A Cognitive approach to improving immersion students“ oral language abilities: the awareness-practice-feedback sequence. In Robert DeKeyser (Ed.), Practice in a Second Language: Perspectives from Applied Linguistics and Cognitive Psychology (pp. 141-160). Cambridge: Cambridge University Press.

Rodgers, Daryl M. (2006). Developing content and form: encouraging evidence from Italian content-based instruction. The Modern Language Journal, 90(3), 373-386. 
Rodgers, Daryl M. (2015). Incidental language learning in foreign language content courses. The Modern Language Journal, 99(1), 113-136.

Saito, Kazuya and Lyster, Roy. (2011). Effects of form-focused instruction and corrective feedback on L2 pronunciation development of / $\mathrm{d} /$ by Japanese learners of English. Language Learning, 62(2), 595-633.

Schleppegrell, Mary J. (2016). Plenary speech content-based language teaching with functional grammar in the elementary school. Language Teaching, 49(1), 116-128

Södergard, Margareta. (2008). Teacher strategies for second language production in immersion kindergarten in Finland. In Tara Fortune and Diane Tedick (Eds.), Pathways to Bilingualism and Multilingualism: Evolving Perspectives on Immersion Education (pp. 152-173). Clevedon, UK: Multilingual Matters.

Spada, Nina and Fröhlich, Maria. (1995). Communicative orientation of language teaching observation scheme. National Center for English Language Teaching and Research. Macquarie University.

Spada, Nina. (2011). Beyond form-focused instruction: reflections on past, present and future research. Cambridge University Press, 44(2), 225-236.

Spada, Nina, Jessop, Lorena, Tomita, Yasuyo, Suzuki, Wataru and Valeo, Antonella. (2014). Isolated and integrated form-focused instruction: effects on different types of L2 knowledge. Language Teaching Research, 18(4), 453-473.

Swain, Merrill. (1996). Integrating language and content in immersion classrooms: research perspectives. The Canadian Modern Language Review, 52(4), 529-548.

Tedick, Diane and Young, Amy I. (2014). Fifth grade two-way immersion students' responses to form-focused instruction. Applied Linguistics, 37(6), 784-807.

Tomita, Yasuyo and Spada, Nina. (2013). Form-focused instruction and learner investment in L2 communication. Modern Language Journal, 97(3), 591-610.

Universidad Juárez Autónoma de Tabasco, México. (2010). Plan de estudios de la licenciatura en idiomas 2010. Tabasco, México: UJAT.

Xanthou, Maria. (2011). The impact of CLIL on L2 vocabulary development and content knowledge. English Teaching: Practice and Critique, 10(4), 116-126.

Yin, Robert K. (2014). Case study research design and methods. United States of America. Sage.

Zyzik, Eve and Polio, Charlene. (2008). Incidental focus on form in university Spanish literature courses. The Modern Language Journal, 92(1), 53-70. 